\title{
SISTEM RESI GUDANG KABUPATEN SUMBAWA
}

\author{
Mujibur Rahmat \\ Program Studi Akuntansi Fakultas Ekonomi dan Bisnis Universitas Teknologi Sumbawa \\ *Corresponding Author email: Mujibur.Rahmat@uts.ac.id
}

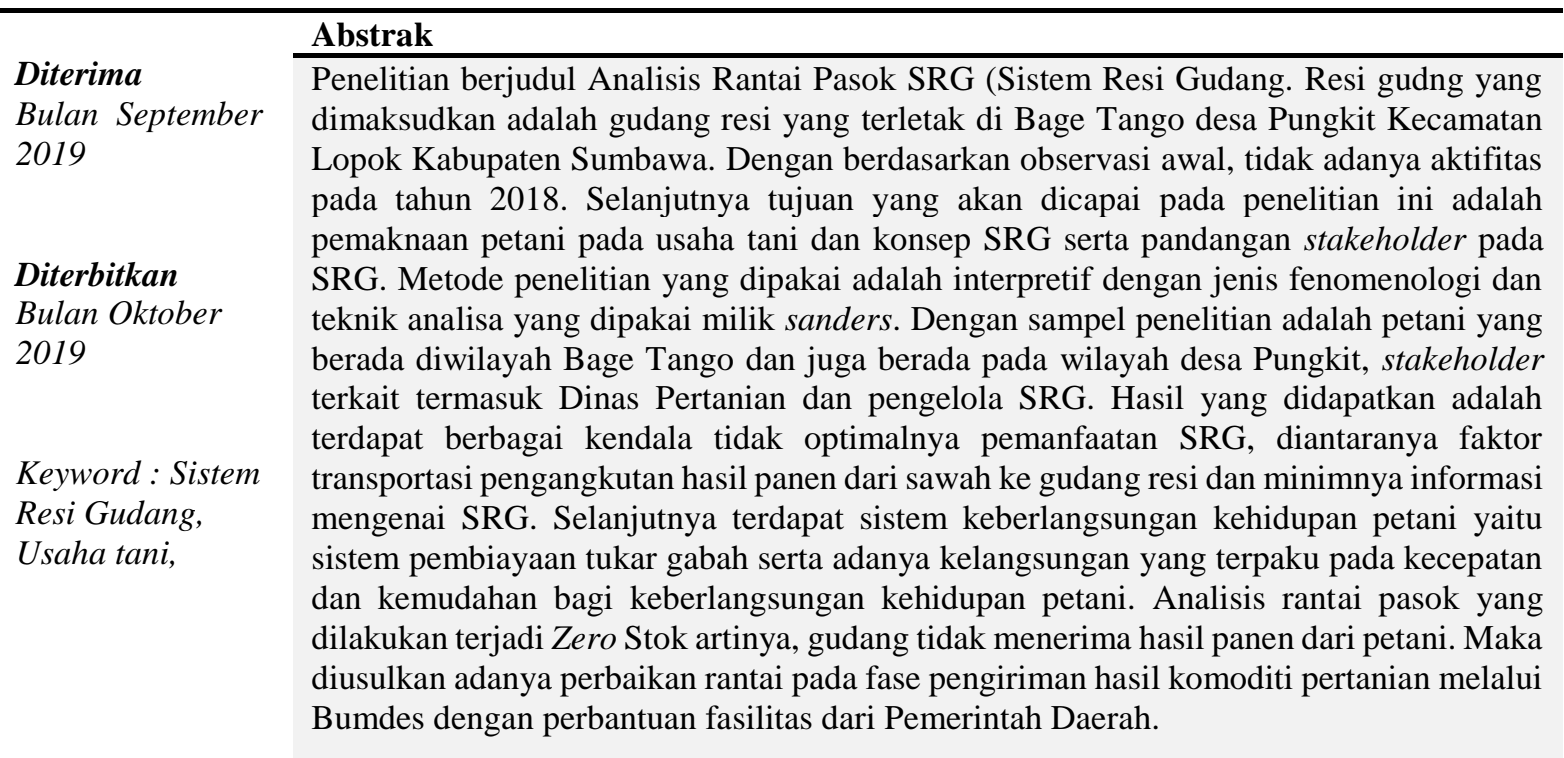

\section{PENDAHULUAN}

Sumbawa merupakan wilayah yang
mempunyai potensi dalam bidang pertanian,
peternakan, dan pariwisata. Potensi pada sektor
pertanian memberikan peluang yang cukup luas untuk
wilayah Sumbawa dalam meningkatkan kesejahteraan.
Terdapat fenomena ketidaktercukupan pendapatan
petani untuk menopang atau memenuhi kebutuhan
hidup sehari-hari. Salah satu penyebabnya adalah
masalah biaya yang tidak seimbang antara biaya tanam
dengan biaya panen (Muhi, 2011).
Berdasarkan atas dasar teori Demand and Supply, yang lebih menekankan pada harga barang yang rendah akan meningkatkan permintaan dan diikuti oleh rendahnya penawaran. Begitu pula sebaliknya bila harga tinggi penawaran akan tinggi dan permintaan akan rendah. Hukum ini secara kasat mata akan terlaksana sesuai dengan kondisi pasar, tetapi pada komoditi pertanian teori tersebut tidak dapat diapilkasikan, karena pada kenyataannya petani sebagai pihak produsen yang mampu memberikan barang justru terbalik menawarkan barang tersebut pada saat ada harga rendah. Berdasarkan hasil observasi sementara, beberapa petani pada saat musim panen dengan ketersediaan gabah yang melimpah tidak mempunyai tempat untuk menyimpan, maka mereka memutuskan gabah terjual ditempat.

Kondisi demikian sepatutnya dapat ditanggulangi melalui sistem tunda jual, sehingga

pada saat barang mulai langka, sementara petani memiliki stok maka dapat menawarkan barang dalam hal ini gabah dengan harga yang optimal. Sehingga ketercukupan pembiayaan tanam dengan panen mampu seimbang bahkan lebih baik. Berdasarkan data dari Bappebti sampai dengan tahun 2016, jumlah gudang pemerintah yang telah memperoleh izin Bappebti sebanyak 80 gudang dimana 65 gudang telah diterbitkan resi gudang, hal ini menunjukkan bahwa prosentase gudang yang telah diterbitkan dan memperoleh pembiayaan sebesar 59,3\% (DPUM, 2018)

.Sementara di wilayah pemerintah Kabupaten Sumbawa dalam kebijakan penerapan SRG telah dievaluasi Kemendag pada tahun 2017. Menurut Tomi Setiawan selaku Kasubag Pemberdayaan Sistem Resi Gudang Kementrian Perdagangan RI sekaligus Pengawas Perdagangan Berjangka Komoditi menyatakan bahwa peranan SRG tidak hanya sebagai pengelola gudang tetapi juga harus menjadi konsultan bagi petani, pada skema penjualan dan pemasaran yang 
tepat. Selanjutnya penerapan SRG di Kabupaten Sumbawa sementara diterapkan di Kecamatan Lopok yang selanjutnya disebut Bage Tango dan Kecamatan Labangka. Sementara pernyataan dari Lang Rudy selaku Kepala Bidang Perdagangan Dinas Koperasi UKM Perindustrian dan Perdagangan memberikan keterangan bahwa SRG di Kabupaten Sumbawa sudah pernah berjalan tahun 2013-2014, dan evaluasi merupakan langkah untuk mendorong dan mengintesifkan SRG sehingga asas manfaat dapat dirasakan petani secara langsung (Using, 2018). maka diperlukan adanya penelitian terkait dengan analisis rantai pasok SRG dengan harapan hasil penelitian mampu mengungkapkan hambatan ketidakoptimalan pemanfaatan SRG di wilayah Bage Tango Kecamatan Lopok.

\section{LANDASAN TEORI}

\section{Resi Gudang}

SRG (Sistem Resi Gudang) adalah kegiatan yang berkaitan dengan penerbitan, pengalihan, penjaminan, dan penyelesaian transaksi resi gudang. Kebijakan resi sistem resi gudang mulai diterapkan pada tahun 2006 oleh pemerintah dengan mengeluarkan undang-undang No. 9 Tahun 2006. Program SRG dikembangkan untuk mengatasi permasalahn petani pada musim panen (Erawan, 2008). RG diartikan sebagai dokumen bukti pemilikan atas barang yang disimpan di gudang yang diterbitkan oleh pengelola gudang, hal ini dijelaskan dala UU SRG No. 9 Tahun 2006. RG terdiri dari dua jenis, yaitu: 1) RG yang dapat diperdagangkan (Negotiabel Werehouse Receipt) yaitu suatu resi gudang yang memuat perintah penyerahan barang kepada siapa saja yang memegang resi gudang tersebut atau atas perintah pihak tertentu. 2) RG yang tidak dapat diperdagangkan (Non Negotiabel Werehouse Receipt) yaitu resi gudang yang memuat ketentuan bahwa barang yang dimaksud hanya dapat diserahkan kepada pihak yang namanya telah ditetapkan.

\section{Proses Penerbitan Resi Gudang}

Berdasarkan Permendag No. 26/MDAG/PER/6/2007, jenis komoditas yang dapat diresigudangkan diutamakan barang untuk ekspor dan untuk ketahanan pangan. Persyaratan komoditas SRG, yaitu (1) mempunyai usia simpan yang cukup lama, minimal 3 bulan, (2) harga berfluktuasi, (3) mempunyai standar-mutu tertentu, (4) mempunyai pasar dan informasi harga yang jelas, dan (5) komoditi potensial dan sangat berperan dalam perekonomian daerah setempat dan nasional. Jenis komoditas SRG mencakup gabah, beras, jagung, kopi, kakao, lada, karet, dan rumput laut, dan tahun 2011 ditambah rotan dan garam. Selain komoditas tersebut, dapat juga disimpan di gudang dengan mempertimbangkan rekomendasi dari Pemerintah Daerah, instansi terkait, atau asosiasi komoditas dengan tetap memperhatikan persyaratan komoditas yang diatur dalam Permendag.

Penerbitan RG memiliki beberapa tahapan yang prosedurnya telah diatur oleh Bappebti. Alur penerbitan RG disajikan pada Gambar 1 Prinsipnya, barang yang akan diresigudangkan harus memenuhi standar yang ditetapkan pengelola gudang. Oleh karena itu, seluruh barang harus melewati tahap uji mutu dan penjaminan barang. Dokumen RG akan diterbitkan Pengelola Gudang setelah seluruh persyaratan terpenuhi. Seluruh data yang terkait dengan penerbitan RG akan masuk ke sistem informasi RG di Pusat Registrasi.

\section{METODE PENELITIAN}

Kondisi ketidakoptimalan pendapatan petani ditinjau dari harga komoditas, dapat diamati pada saat panen raya. Alternatif tunda jual gabah jarang sekali dijadikan pilihan bagi petani, dengan alasan keterdesakan terhadap kebutuhan hidup dan keberlanjutan musim tanam berikutnya. Dari kondisi seperti ini maka SRG sebagai alternatif untuk menyelamatkan anjloknya harga komoditas pertanian pada saat panen raya. SRG adalah sistem dimana petani dapat menitipkan hasil komoditas pertaniannya pada gudang dan mendapatkan sertifikat kepemilikan yang disebut dengan resi gudang dari hasil komoditas pertanian. Nantinya dapat dijadikan jaminan untuk mendapatakan dana dari lembaga tertentu (Perbankan), atau petani dapat menunggu waktu pada saat harga gabah mengalami peningkatan maka dapat mengambil pada gudang dan menjualnya sehingga menigkatkan pendapatan dibandingkan dengan penjualan secara langsung pada saat panen raya.

Dikaji secara konseptual, SRG adalah konsep yang memberikan penawaran kemudahan dan kelebihan dalam membantu petani untuk memperoleh harga yang optimal dan sekaligus sebagai solusi atas pembiayaan usaha tani. Namun demikian, fenomena yang terjadi adalah kurangnya pemanfaatan SRG di Bage Tango Kecamatan Lopok. Maka, diperlukan 
adanya analisis terhadap pemanfaatan SRG atau analisis rantai pasok SRG sampai pada kendala yang dirasakan oleh petani pada wilayah Bage Tango dalam pemanfaatan SRG.

Lokasi penelitian dipilih secara purposive berdasarkan pertimbangan adanya wilayah sasaran penerapan SRG yaitu wilayah Bage Tango Kecamatan Lopok. Sementara responden terdiri dari penentu kebijakan, perencana dan pelaksana teknis di dinas tingkat Kabupaten, pelaksana SRG di tingkat Kecamatan dan Desa, pengelola SRG, petani pengguna SRG dan Petani bukan pengguna SRG. Jenis data yang diapaki adalah data primer dan sekunder. Metode analisis adalah analisis kebijakan dengan melakukan riview dan analisis mendalam pada ssistem mata rantai SRG dan pendekatan yang diapaki dalam penelitian ini adalah pendekatan paradigm interpretif..

Teknik analisis data yang diapaki dalam pendekatan interpretif yaitu metode fenomenlogi mengutip dari Sande3rs (1982) dengan menggunakan empat tahapan 1) Deskripsi fenomena, 2) Identifikasi tema-tema, 3) Mengembangkan noematic/noesis correlates, 4) Abstraksi intisari atau universal dari noematic/noetic correlates. Semnetara pencermatan keasbahana data dengan uji kredibiltas melalui perpanjanagn observasi dan triangulasi. (waktu dan teknik) dengan mnggunakan infoermasn yaitu petani dan stakeholder yang terkait dengan system resi gudang di kecamatan Pungkit.

\section{HASIL DAN PEMBAHASAN}

\section{Fluktuasi Harga Jual Gabah}

Berdasarkan Inpres No. 5 tahun 2015, harga GKP (Gabah Kering Panen) Rp. 3.700 per kilogram, GKG (Gabah Kering Giling) dengan kadar air maksimum $14 \%$ Rp. 4.600 per kilogram ditingkat penggilingan dan Rp. 4.650 di tingkat bulog. Inpres ini dimaksudkan untuk menjaga stabilitas harga guna membantu petani dalam memprediksi keseluruhan biaya dan pendapatan yang akan diterima.

Fenomena yang terjadi pada Desa Pungkit tidak sesuai harapan dari Inpres tersebut. Petani justru banyak mengalami kerugian dari hasil tani. Hal ini bukan karena faktor kuantitas dari gabah yang dihasilkan, tetapi terdapat ketidakstabilan harga jual gabah. Hasil dari berbagi interview dan analisis perhitungan penjualan gabah maka didapatkan kondisi fluktuasi harga yang tidak sesuai hukum permintaan dan penawaran. Faktor yang mempengaruhi ada;ah kualitas harga gabah dengan kandungan air yang masih tinggi. Hal ini dipengaruhi oleh konidsi cuaca pada saat petani dalam proses pemanenan hasil pertanian.

\section{Pemahaman Tunda Jual atau SRG}

Tunda jual ini merupakan sebuah antisipasi harga gabah yang jatuh pada saat musim panen sekaligus sebagai upaya petani padi dalam meningktakna pendapatan usaha tani padi, maka sebagian petani melakukan tunda jual (Omnumah, 2003). konsep tunda jual sebenarnya dipahami hanya sebatas bagaimana menunda penjualan untuk mendapatkan harga tinggi. Terbenturnya tempat penyimapanan gabah menjadikan sistem tunda jual menjadi tidak efektif. Selain itu hal yang menunjang tidak efektifnya sistem tunda jual adalah faktor biaya penanaman kembali dan juga kebutuhan hidup.

Selanjutnya pemahaman mengenai resi gudang yang sebenarnya telah ada pada sekitar wilayah penelitian mendapatkan respon yang berbeda. Hasil wawancara yang didapatkan, beberapa petani tidak memahami maksud didirikannya resi gudang, bagaimana prosedur dan manfaat yang didapatkan oleh mereka. Tidak terpakaianya resi gudang menjadi semakin kurangnya pemanfaatan gudang tersebut. Ketidaktahuan pemanfaatan gudang resisebagai akibat dari minimnya informasi dari hasil sopsialsisasi SRG.

\section{Manajemen Biaya Pertanian}

Biaya pertanian yang didapatkan pada fakta dilapangan diantaranya, biaya bibit atau benih, pupuk, pestisida, upah kerja yang terdiri dari pengolahan lahan, penanaman dan penyulaman, pemeliharaan, pemupukan, pemanenena, perontokan, sewa lahan, sewa alat atau sarana usaha, bahan bakar, dan biaya lainnya.

Biaya yang timbul atas proses produksi pertanian, tidak mampu di kalkulasikan secara pasti oleh para petani didesa pungkit. Sistem perkiraan pembiayaan menjadi pemicu utama terhadap tingginya akumulasi biaya pertanian. pemahaman pembiayaaan pertanian yang dipahami oleh petani tidak terkonsep seperti teori, sehingga keuntungan maksimal yang di dapatkan oleh petani tidak terhitung secara jelas. Dari hasil pengamatan inilah dapat ditarik kesimpulan bahwa pendapatan petani yang tidak maskimal juga terhalang oleh pemahaman konsep pembiayaan pertanian.

\section{Kondisi Ideal Pasokan SRG}

Kondisi pertama, pihak SRG adalah sebagai pihak yang hanya menerima tanpa adanya aktifitas lainnya pada prapasok. Sementara petani sebagai 
pemilik komoditi bertugas melakukan pengiriman pada opihak SRG. Kondisi ini merupakan kondisi ideal awal yang terbangun sejak berdirinya SRG. Posisi petani hanya sebagai pemilik komoditi yang menanggung segala biaya sampai pada saat barang diterima oleh pihak SRG. Pihak SRG sebagai pengelola menjalankan aktifitas sesuai dengan standar pengelolaan yang telah diatur oleh Bapetti sampai timbulnya resi gudang yang didapatkan oleh petani pemilik komoditi.

Kondisi Kedua, menunjukkan kondisi ideal bagi SRG yang menunjukkan melimpahnya komoditi pertanian, yang seharusnya dapat terdistribusikan ke gudang secara baik sebagai pemasok. Tetapi pada gambar kedua, menunjukkan bahwa pada gudang resi terjadi Zero activity, artinya terdapat ketimpangan antara harapan banyaknya komoditas pertanian dengan nol pasokan yang terdapat pada SRG. Sehingga pihak pengelola sama sekali tidak menerbitkan resi untuk petani. Kondisi inilah yang menyebabkan ketidak idealan tujuan utama dibentuknya SRG. Dari arah panah dan dari hasil penelitian yang sebelumnya telah dijabarkan, terdapat kendala, salah satunya yaitu proses pengiriman dari petani dan SRG yang membutuhkan transportasi dan hal ini sangat minim dimiliki oleh petani.

Kondisi ketiga, aktifitas pemasokan barang yang dilakukan oleh patani kepada SRG dengan menggunakan jasa pengangkutan. Hal ini merupakan pilihan pertama apabila petani tidak memiliki transportasi. Model ini memiliki kelemahan pada pembayaran atau pembiayaan pengangkutan oleh petani sampai pada SRG, yaitu biaya yang sifatnya harus dibayar secara tunai kepada jasa pengangkutan

Kondisi keempat, adanya pihak lain yang membantu untuk mendukung pasok barang SRG, yaitu pada bantuan Pemda dalam pengadaan alat transportasi pengangkutan komoditi petani hingga ke gudang resi. Alat ini dapat diberikan pada BUMDES sebagai penanggungjawab pengelola. Dengan model seperti ini maka BUMDES akan lebih operasional dalam wujudnya sebagai keterlibatan dalam pelaksanaan keberlangsungan kehidupan pedesaan

\section{PENUTUP}

\section{Kesimpulan}

Beberapa kesimpulan yang dapat ditarik dari hasil penelitian ini yaitu: Pertama, petani belum secara utuh memahami konsep Sistem Resi Gudang yang terdapat di Bage Tango Desa Pungkit sehingga diperlukan adanya Edukasi pengelolaan pertanian dengan model bisnis SRG. Kedua, pemanfaatan SRG tidak menyentuh petani, dikarenakan terdapat beberapa kendala, diantaranya yaitu faktor transportasi yang minim untuk membawa hasil komoditi sebagai pasokan utama SRG. Ketiga, SRG merupakan suatu instrumen pemerintah yang berpihak pada petani dan dapat dijadikan sebagai solusi pada kondisi perekonomian inflasi maupun deflasi. Strategi penghidupan yang dipakai oleh petani Desa Pungkit adalah sistem pembiyaan yang tidak sesuai dengan manajemen biaya sehingga model peminjaman dengan tukar gabah sebagai keberlanjutan penghidupan, kecepatan dan kemudahan yang ditawarkan oleh pihak pengepul adalah pilihan yang menarik bagi petani.

\section{REFERENSI}

Ashari. (2007). Resi Gudang: Alternatif Model Pemasaran Komoditas Pertanian, wrata Penelitian dan Pengembangan. Badan Penelitian dan Pengembangan Pertanian, 29(4):7-8.

BPS. (2017).Data BPS. Retrieved from Badan Pusat Statistik: www.bps.go.id

Dinas Pertanian. (2017, November 07). Luas Lahan Baku Kabupaten Sumbawa Tahun 2016. Retrieved from Dinas Pertanian Kabupaten Sumbawa: www.distansumbawa.com

DPUM. (2018, 02 13).Penelitian: KAjian Peningkatan Pemanfaatan Sistem Resi Gudang. Retrieved from Bank Indonesia: www.bi.go.id

Erawan, B. (2008). Prinsip Hak Jaminan Resi Gudang dalam Perspektif Perbankan : Kajian Normatif Pemberdayaan Petani Gabah pada Musim Panen.Jurnal Argumentum, Vol 8 Nomor 1.

iPasar. (2011). Implementasi Pelaksanaan Pasar Lelang Dalam Mendukung Sistem Resi Gudang.Workhsop Penguatan Kelembagaan SIstem Resi Gudang dalam MEndukung PEmbiayaan Sektor Pertanian. Jakarta.

Moleong, L. (2005).Metodologi Penelitian Kualitiatif. Bandung: Remaja Rosdakarya.

Muhadjir. (2000). Metodologi Penelitian Kualitatif Edisi $I V$. Yogyakarta: Rake Sarasin.

Muhi. (2011). Fenomena Pembangunan Desa. 2011: Institut Pemerintahan Dalam Negeri. 
Peraturan Menteri Perdagangan RI. (2007).PP NO. 26/M-DAG/PER/2007 Tentang Barang Yang Dapat Disimpan di Gudang Dalam Rangka Penyelenggaraan SRG. Jakarta: Sekretariat Jendral Departemen Perdagangan.

PP NO 36 TAHUN 2007. (2007). Tentang Pelaksanaan UU No.9 Tahun 2006 Tentang Sistem Resi Gudang . Jakarta: Tambahan Lembaran Negara RI Nomer 4735.

Putri, N. (2012). Sistem Resi Gudang Solusi Bagi Petani. Retrieved from Badan Pengawas Perdagangan Berkjangka Komiditi: www.bapebbti.go.id

Republik Indonesia. (2006).UU No 9 Tahun 2006 Tentang Sistem Resi Gudang. Jakarta: Lembaran Negara Republik Indonesia 2006 Nomer 59.

Teken,, I., \& Hamid, A. (1982). Tataniaga Pertanian. Bogor: Institut Teknologi Bogor (IPB).

Triyuwono, I. (2009). Prespektif, Metodologi, dan Teori Akuntansi Syariah. Jakarta: Raja Grafindo.

Using, P. (2018, Januari). Kemendag Evaluasi Kesiapan SRG Sumbawa. Retrieved from Kabar Sumbawa: www.kabarsumbawa.com 